\title{
Te vagy az én Hősöm! Történet gyermekeknek gyermekekről és a COVID-19 nevü vírusról
}

\author{
"My Hero is You" A new fictional book developed by and for \\ children aims to help families understand and cope with COVID-19.
}

Szerző: $\quad$ Bíróné Asbóth Katalin $\square$

Heim Pál Országos Gyermekgyógyászati Intézet Módszertani Igazgatóság, Budapest

Beküldve: $\quad$ 2020. 07. 22.

doi: $\quad$ 10.24365/ef.v61i3.612

Kulcsszavak: koronavírus; járvány; gyermekmese; egészségértés

Keywords: coronavirus; epidemic; children's fairy tale; health literacy

Ezt a kis mesekönyvet gyermekeknek írták, akik a világon bárhol találkoznak a koronavírus járvánnyal. A rajzokkal gazdagon illusztrált kedves történetek segítenek a gyermekeknek, hogy az ismeretlen fogalmak, új viselkedésformák számukra a mindennapi gyakorlatban is érthetővé váljanak, ne keltsenek szorongást, sőt inkább pozitív megerősitést kapjanak.

A történetet különösen a szülők, nagyszülők, gondozók, vagy óvónők, tanárok figyelmébe ajánljuk, akik a gyermekre, vagy kisebb gyermekcsoportra felügyelnek. A Szerzők javasolják, hogy a gyermekek lehetőleg szülő, gondozó, vagy tanár jelenlétében, tudtával olvassák. Segíthet a feldolgozásban, ha a gyermekek lerajzolják, vagy eljátsszák a történet egyes részeit, esetleg beszélgetnek róla.
A jelen fordítást/ adaptációt nem az Inter-Agency Standing Comettee (IASC) készitette. A szervezet nem felelös a fordítás tartalmáért és pontosságáért. Az eredeti angol kiadás az Inter-Agency Standing Comittee által jóváhagyott My Hero is You: How Kids Can Fight COVID-19! A érvényes eredeti kiadás engedélyezése a CC BY-NC-SA 3.1 IGO szerinti történt.

Az eredeti kiadvány elérhető:

https://www.unicef.org/coronavirus/my-hero-you

A WHO kiadványt magyarra fordította: HOGYI Módszertani Igazgatóság, Bíróné Asbóth Katalin

A magyar változat elérhető:

https://gyogyhirek.hu/tortenet-gyermekeknekcovid-19-virusrol/ 